\title{
THE INFLUENCE OF WeLding PARAMETERS ON TEMPERATURE DISTRIBUTION IN CASE OF EBW
}

\author{
Grecu, L.; Demian, G.; Demian, M. \& Grecu, V.
}

Abstract: This paper presents a mathematical and numerical model for the temperature distribution into a workpiece during electron beam welding (EBW). The mathematical modeling is based on the heat equation and on the specific phenomena that arise whenever the electron beam interferes with the matter, like the penetration of the electrons into the target. A MathCAD application developed on the mathematical and numerical model proposed is used to study the influence of the welding variables, such as the accelerating voltage, beam power and beam radius, as well as the material characteristics on the temperature field.

Key words: electron, welding, parameters, temperature
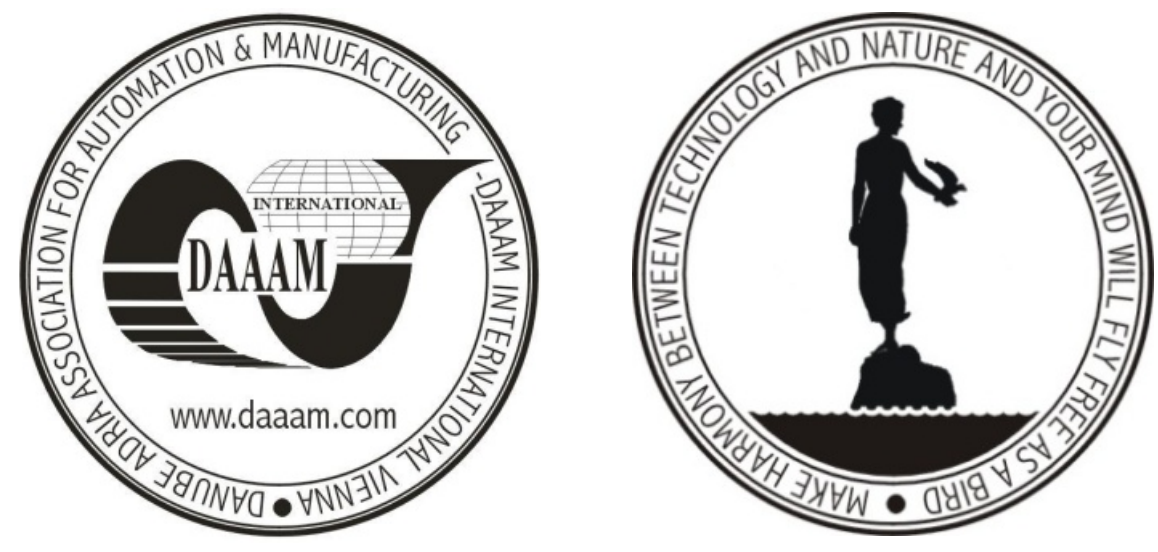

Authors data: Asist. prof. dr. mat. Grecu, L[uminita]; Assoc. prof. dr. Demian, G[abriela]; Assoc. prof. dr. Demian, M[ihai]; Drd. eng. Grecu V[alentin], University of Craiova, Faculty of Engineering and Management of Technological Systems, lumigrecu@hotmail.com, gabrielademian@yahoo.com, mihaidemian@yahoo.com, vali.grecu@imst.ro

This Publication has to be referred as: Grecu, L[uminita]; Demian, G[abriela]; Demian, M[ihai] \& Grecu, V[alentin] (2009). The Influence of Welding Parameters on Temperature Distribution in Case of EBW, Chapter 05 in DAAAM International Scientific Book 2009, pp. 035-044, B. Katalinic (Ed.), Published by DAAAM International, ISBN 978-3-901509-69-8, ISSN 1726-9687, Vienna, Austria DOI: $10.2507 /$ daaam.scibook.2009.05 